\title{
Angelman sindromearen tratamendurako itu terapeutikoen bila: USP9X deubikuitinasa jomugan
}

\author{
Searching for Angelman syndrome therapeutical targets: deubiquitinase USP9X \\ in the spotlight \\ Nagore Elu, Juanma Ramirez, Benoit Lectez, Nerea Osinalde, Ugo Mayor \\ ${ }^{1}$ Biokimika eta Biologia Molekularra Saila, Zientzia eta Teknologia Fakultatea. Euskal Herriko \\ Unibertsitatea, UPV-EHU, 48940 Leioa, Bizkaia. \\ ${ }^{2}$ Biokimika eta Biologia Molekularra Saila, Farmazia Fakultatea, Euskal Herriko \\ Unibertsitatea, UPV-EHU, 01006 Gasteiz, Araba. \\ ${ }^{3}$ Ikerbasque, Basque Foundation for Science, Bilbo, Bizkaia.
}

nagore.elu@ehu.eus

\section{Laburpena}

UBE3A proteinaren gabeziak Angelman sindromea sorrarazten du. Proteina horrek zelulako beste proteina batzuk ubikuitinatzen ditu, haien funtzioa erregulatuz. Hortaz, UBE3A falta denean, bere substratuak -DDI1 kasu- gutxiago ubikuitinatuko dira, ondorio larriak ekarriz. Horrez gain, deubikuitinasa deritzen proteinek substratuen ubikuitina kentzean, egoera larritzen da. Lan honetan DDI1 substratutik ubikuitina ketzen duen proteinetako bat - USP9X - identifikatu dugu eta itu terapeutiko gisa aurkeztu dugu, zeren berau inhibitzeak DDI1 proteinaren ubikuitinazioa emendatu eta gaixotasunaren eredu diren eulien sintomatologia hobetzen baitu.

Gako-hitzak: Angelman sindromea, UBE3A proteina, ubikuitina, deubikuitinasa, farmakoa.

\section{Abstract}

Lack of UBE3A protein causes Angelman syndrome. This protein is in charge of ubiquitinating other proteins in the cell. Therefore, when there is lack of UBE3A, its substrates - such as DDI1- will be less ubiquitinated, negatively affecting cell equilibrium. Moreover, proteins named deubiquitinases remove ubiquitin from the substrates, making the scenario even worse. In this work we have identified one of the proteins -USP9X - that deubiquitinates DDI1 and presented it as a therapeutical target, since its inhibition enhances DDI1 ubiquitination and improves the climbing ability of Angelman syndrome model flies.

Keywords: Angelman syndrome, UBE3A protein, ubiquitin, deubiquitinase, drug.

Bidalia: 2019ko ekainaren 6an.

Onartua : 2019ko ekainearen 11n.

https://doi.org/10.26876/osagaiz.1.2019.262 


\section{Sarrera}

Gure genoma errezeta-liburu bat bezalakoa da, eta zelula, berriz, sukaldaria; izan ere, genoman dagoen informazioa erabiltzen du bere langileak izango diren proteinak sortzeko. Genoman milaka gene edo errezeta ditugu, eta gene horietako bakoitzak proteina bat ekoizteko informazioa dauka. Proteina guztiek funtzio konkretu bat dute zelularen barruan. Hortaz, errezeta-liburuko orriak falta badira - delezioak - edo testuan akatsak badaude mutazioak-, litekeena da proteinarik ez sortzea, edo sortuz gero, akastuna izatea. Edozein kasutan, proteinak ez du zelulan dagokion funtzioa burutuko, eta horrek maiz ondorio larriak eragiten ditu. Hain zuzen ere, hori da Angelman sindromean (AS) gertatzen dena. Burmuinean UBE3A deritzon genearen galeraren edo mutazioaren ondorioz, gene horrek kodetzen duen UBE3A proteina ez da sortzen edo akastuna da, eta horrek burmuineko funtzioetan nahasmenduak sortzen ditu (1) (1. irudia). AS pairatzen duten banakoen ezaugarri bereizgarrienak hauek dira: adimen-urritasuna, orekaren nahasmendua, hitz egiteko zailtasunak eta etengabeko irribarrea (2).

1. irudia. Angelman sindromea duten hiru pertsona, hain esanguratsua duten irribarrearekin. UBE3A genean mutazioak edo akatsak daudenean, ez da UBE3A proteinarik sortzen eta sindromea garatzen da.
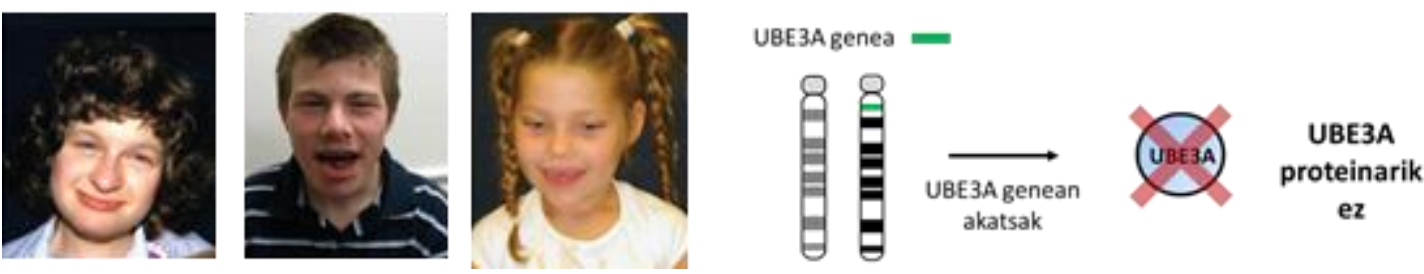

ez

Baina, nola da posible proteina bakar baten faltak burmuinean horrelako eragin latza izatea? Galdera horri erantzuteko, lehendabizi, UBE3A proteinak zer egiten duen argitu behar da. Aurrez aipatu bezala, proteinak zelulako langileak dira, eta bakoitzak funtzio konkretu bat betetzen du. UBE3A proteina zelulako agintarietako bat da eta beste proteina batzuei zein funtzio bete behar duten adierazteaz arduratzen da. Eta nola egiten du hori? Bada, proteinei post-it gisa funtzionatzen duen molekula bat gehituz, hots, ubikuitina gehituz. Proteina bati itsatsitako ubikuitina kantitatearen eta horiek proteinara lotzeko moduaren arabera, proteinak jasoko duen agindua desberdina izango da (3) (2A. irudia). Alabaina, ubikuitina bidez eman daitezkeen aginduak asko dira. Oraintsu frogatu da ubikuitinazioak proteina bat degradatu egin behar dela adierazteaz gain (4), zelulan lekuz aldatu behar dela (5), edo zelulako beste prozesu batzuk aktibatu behar direla (6) esateko ere balio duela (2B. irudia). Hortaz, UBE3A proteina zelulako proteina ezberdinak ubikuitinatzeaz arduratzen dela jakinik, logikoa da pentsatzea bere gabeziaren ondorioz proteina horiek agintaririk gabe gelditzen direnez, zelularen oreka hautsi egiten dela.

Ildo beretik, zelulan badira UBE3A proteinaren aurkako funtzioa betetzen duten proteinak, hots, proteinei ubikuitina post-it-a kentzeaz arduratzen direnak. Deubikuitinasa (DUB) izenez ezagutzen dira proteina horiek (7). Hortaz, osasun-egoeran, UBE3Ak eta DUBek gidatutako proteinen ubikuitinazioa eta ubikuitina kentzea, hurrenez hurren, oso zehazki erregulatutako prozesuak dira (2B. irudia). 
2. irudia. (A) Ubikuitina bidezko mezuak desberdinak izan daitezke ubikuitinak lotzeko moduaren arabera. (B) Proteinen ubikuitinazioaz arduratzen da UBE3A proteina; deubikuitinasek, aldiz, alderantziz jarduten dute, ubikuitina hori gehiago behar ez denean proteinetatik kenduz.

(A)

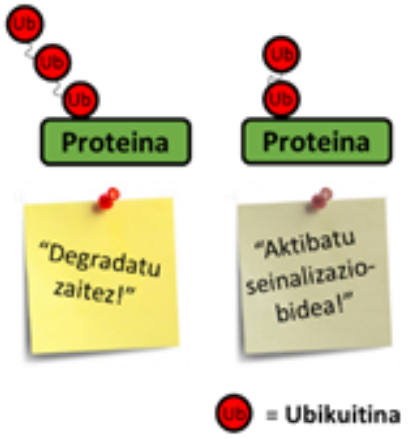

B

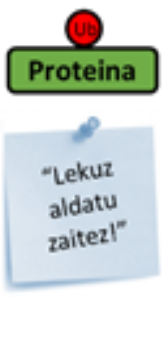

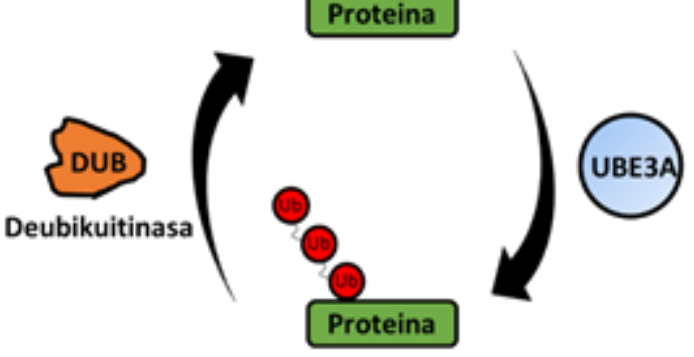

Arestian aipatu bezala, Angelman sindromea UBE3A proteinaren faltagatik sortzen da, eta hortaz gaixotasuna sakon ulertzeko ezinbestekoa da ezagutzea zeintzuk diren gabezia horren ondorioz neuronetan agintaririk gabe, hots, ubikuitinatu gabe, gelditzen diren proteinak. Oraintsu ezagutu ditugu proteina horietako batzuk, eta horien artean dago DDI1 deituriko proteina (8).

DDI1 zelulako garbitzailea da; degradatu behar diren proteinak birziklapen-fabrikara, hau da, proteasomara, eramaten ditu (4). Hortaz, bistakoa da UBE3Aren gabeziaren ondorioz DDI1 proteinaren jarduera ez bada egokia, zelularen birziklapen-prozesua kalte daitekeela. Alabaina, oraindik ez da ezagutzen zein den UBE3A proteinak DDI1 proteina ubikuitina bidez markatzean ematen dion agindua, ezta zein den markaketa hori kentzeaz arduratzen den deubikuitinasa.

\section{Arloko egoera eta ikerketaren helburuak}

UBE3A proteina akastuna denean edo ekoizten ez denean, hots, ASa pairatzen dutenen kasuan gertatzen den bezala, DDI1 proteinaren ubikuitinazio-maila behar baino txikiagoa izatea aurreikusten da. Horrez gain, deubikuitinasek DDI1 proteinak duen ubikuitinazio gutxi hori kentzen badute, egoera are larriagoa izango da. Beraz, DUB horiek inaktibatuz DDI1 proteinaren ubikuitinazio-maila egokia berreskuratzea lortuko balitz, gaixotasunaren sintomatologia hobetuko litzatekeelakoan gaude. Hori kontuan izanda, gure ikerkuntzan hiru helburu ditugu:

1) UBE3A proteinak DDI1 proteinan jarritako ubikuitina kentzeaz arduratzen den deubikuitinasa identifikatzea.

2) Deubikuitinasa hori inhibitzen duen farmako bat erabiliz, DDI1 proteinaren ubikuitinaziomaila berreskuratzen denetz aztertzea.

3) DUBa inhibitzen duen farmakoa erabiliz, Angelman sindromearen eredu diren eulien sintomatologia aztertzea.

\section{Ikerketaren muina}

\subsection{DDI1 proteinari ubikuitina kentzeaz arduratzen den DUBaren identifikazioa}

Proteinen ubikuitinazioa laborategian aztertzeko prozesu nahiko konplexua da; izan ere, ubikuitinatzen diren proteinak populazioaren gutxiengoa (\% 1-5) dira. Beraz, proteina konkretu baten ubikuitinazio-maila aztertu nahi bada, nahitaez proteina konkretu hori arrantzatu 
beharra dago, ondoren sakon aztertu ahal izateko. Kasu honetan DDI1 proteinaren ubikuitinazio-maila neurtu nahi dugu, berau ubikuitina gabetzeaz arduratzen den DUBa identifikatzeko. Hortaz, DDI1 arrantzatu behar dugu. Baina nola? Bada, DDI1 proteinari GFP (Green Fluorescent Protein) isatsa gehituz, eta ondoren GFParekin lotzen den amua daukan kanabera erabiliz (3. irudia).

3. irudia. DDI1 proteinari fluoreszentea den proteina bat (GFP) itsasten zaio, horren aurkako "amuarekin" zelulako proteina guztien artean arrantzatu ahal izateko eta ubikuitinazio-maila neurtzeko.

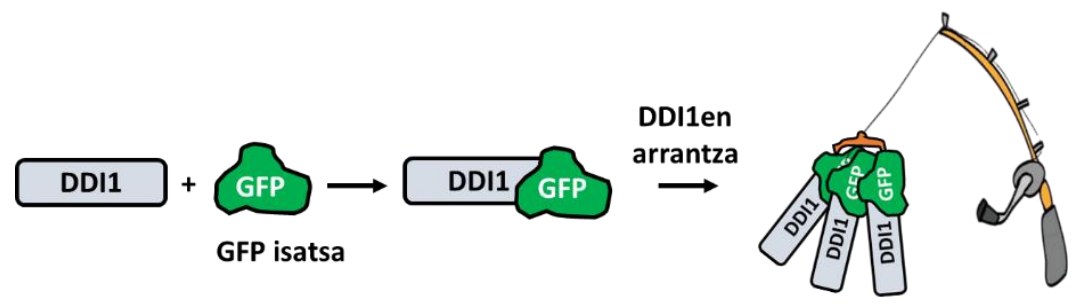

Batetik, DDI1-GFP proteina fluoreszentea denez, fluoreszentziazko mikroskopioarekin beha daiteke bere kokapena eta adierazpen-maila ezagutzeko (4A irudia). Bestetik, eta guretzako interesgarriagoa izanik, isats hori harrapatzen duen "amua" daukagunez, DDI1 proteina arrantza dezakegu, eta ubikuitina ezagutzen duten antigorputzak erabiliz, bere ubikuitinaziomaila neur dezakegu (4B irudia).

4. irudia. GFP isatsaren erabilerak DDI1 proteinan. (A) GFP isatsari esker fluoreszentziazko mikroskopioan beha daiteke DDI1-GFP proteinaren adierazpena HEK293T zeluletan. (B) GFP isatsarekin batzen den kanabera erabiliz, DDI1 proteina arrantza dezakegu. Jarraian, antigorputzen bidez proteina honen ubikuitinazio-maila ere neur dezakegu.

A

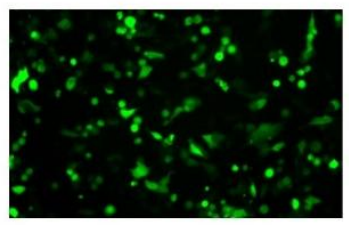

Fluoreszentzia bidezko DDI1GFP proteinaren jarraipena
B

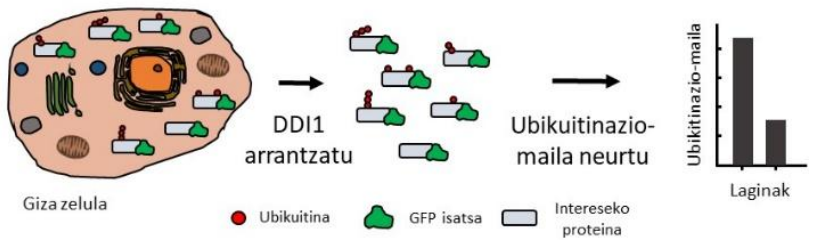

DDI1-GFP proteinaren arrantza eta ubikuitinazio-maila neurtzea

Giza zeluletan 100 DUB ezberdin inguru daude. Horietatik DDI1 proteinatik ubikuitina kentzen duena zein den jakiteko, zelula-populazio ezberdinetan DUB bana desagerrarazi edo isildu dugu. Deubikuitinasaren absentzian, bere itu-proteinetan ez da ubikuitina ezabatuko, eta, beraz, azken horien ubikuitinazio-maila igo egingo da. Hortaz, DUBen bat isildu eta DDI1aren ubikuitinazio-maila emendatzen dela detektatuz gero, DUB hori DDI1 proteinatik ubikuitina kentzeaz arduratzen dela ondorioztatuko dugu.

Esperimentu horretarako HEK293T zelulez betetako 6 putzutxoko plakak erabili ditugu, eta putzutxo bakoitzean DDI1-GFPa gehitzeaz gain, deubikuitinasa bat isildu dugu dagokion siRNAa erabiliz (5A irudia). Ondoren putzutxo bakoitzean DDI1-GFPa arrantzatu, eta antigorputzen bidez bere ubikuitinazio-maila neurtu dugu. Testatutako deubikuitinasen artetik lauk dute eragina DDI1 proteinaren ubikuitinazio-mailan: UCHL5, USP7, USP9X eta USP42. Alabaina, erreplikekin egindako bigarren esperimentu batean lau horietatik bakar baten isilpenak - 
USP9X - eman du DDI1 proteinaren ubikuitinazio-mailaren emendapen esanguratsua (5B irudia). Hortaz, USP9X deubikuitinasa da DDI1 proteinari ubikuitina kentzeaz arduratzen dena.

5. irudia. DDI1 ubikuitina gabetzeaz arduratzen den DUB proteinaren identifikazioa. (A) DDI1-GFPa gehitu dugu lagin guztietan, baina putzutxo bakoitzean deubikuitinasa ezberdin bat isildu dugu. Lagin guztietatik DDI1-GFP proteina arrantzatu, eta bere ubikuitinazio-maila neurtu dugu. (B) Aztertutako DUB guztietatik lauk izan duten arren eragina DDI1 proteinaren ubikuitinazioan, soilik USP9X proteinaren kasuan izan da eragina estatistikoki esanguratsua esperimentua hiru aldiz egitean [** $p<0,05$ ANOVA erabiliz ( $n=3)$, u.a.= unitate arbitrarioak].

A

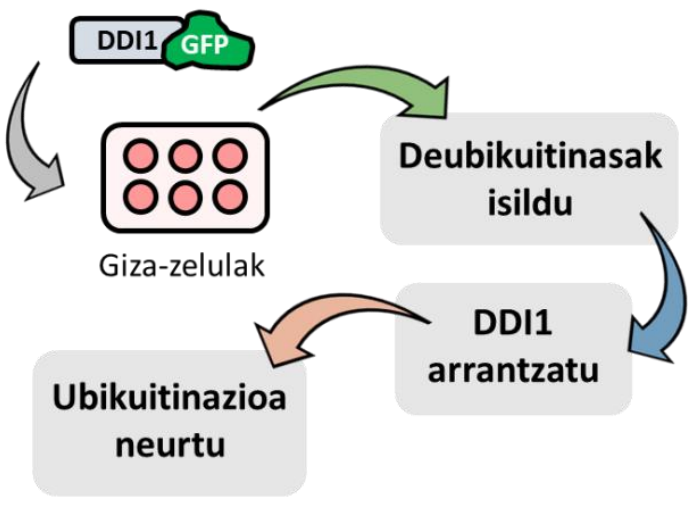

B

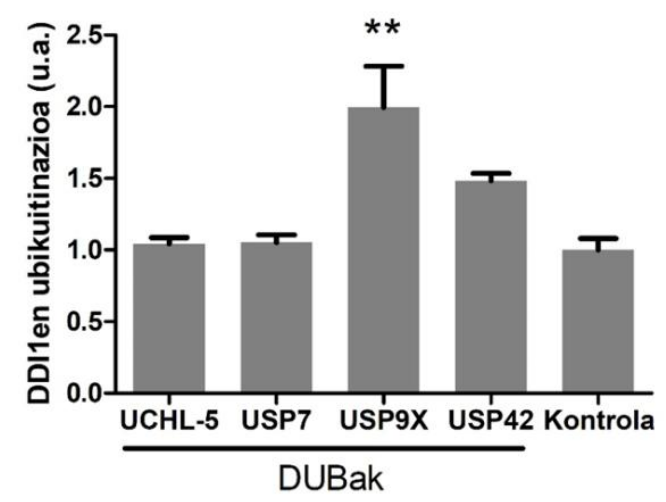

\subsection{USP9X proteinaren aurkako farmakoak DDI1 proteinaren ubikuitinazio-mailan duen eragina aztertzea}

Aurreko atalean ikusi bezala, USP9X isiltzean DDI1 proteinaren ubikuitinazio-maila igo egiten da (5B irudia). Efektu hori Angelman sindromea duten pazienteentzako onuragarria suerta daiteke, gaixoek duten DDI1 ubikuitinatu-maila txikia igotzen lagundu baitezake, haien sintomatologia hobetuz.

Alabaina, zelulekin erabilitako isilpen-teknika ezin da teknikoki pazienteetara hedatu, eta ondorioz, proteina batek jarduteari uzteko modurik erabiliena bere aurkako farmako bat erabiltzea da. Bada USP9Xa inaktibatzen duen merkaturatutako farmako bat: WP1130 edo degrasina deiturikoa. USP9Xaren isilpenarekin lortutako emaitzak, farmako horrekin berresten zirenetz frogatzea izan da gure hurrengo helburua. Izan ere, horrek farmakoa ASaren tratamendu gisa erabiltzeko ateak irekiko lituzke.

Horretarako, aurreko esperimentuan bezala, 6 putzutxoko plakak erabili ditugu. HEK293T zelulei WP1130 farmakoa gehitu diegu, eta beste batzuk farmakorik gabe kontrol gisa erabili ditugu. Zelulak 48 orduz farmakoarekin inkubatu ostean, DDI1-GFP proteina arrantzatu, eta bere ubikuitinazio-maila neurtu dugu (6A irudia). USP9Xaren isilpenarekin lortutako datuekin bat eginez, farmakoarekin ere DDI1en ubikuitinazio-maila modu esanguratsuan emendatzen dela frogatu dugu (6B irudia). Beraz, WP1130 farmakoak USP9X inaktibatu, eta, ondorioz, DDI1en ubikuitinazio-maila emendatzeko gaitasuna duela ondoriozta dezakegu. 
6. irudia. WP1130 farmakoaren eragina giza zeluletan. (A) DDI1-GFP proteina giza zeluletan sartu da. Hiru putzutxoko zelulei 0,7 mM WP1130 farmako gehitu zaie, beste hiru putzutxokoei, berriz, ez, beraz kontrol gisa erabili dira. Ondoren DDI1-GFP arrantzatu, eta bere ubikuitinazio-maila neurtu da. (B) Farmakorik gabeko kontrolarekin alderatuz, WP1130ak DDI1 proteinaren ubikuitinazio-maila modu esanguratsuan emendatzen du [Ttesta, *, $\mathrm{P}<0,05, \mathrm{n}=3, \mathrm{u} . \mathrm{a} .=$ unitate arbitrarioak].

A

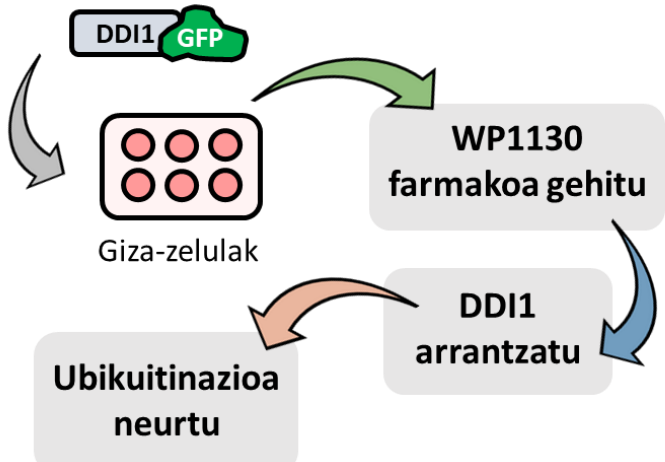

B

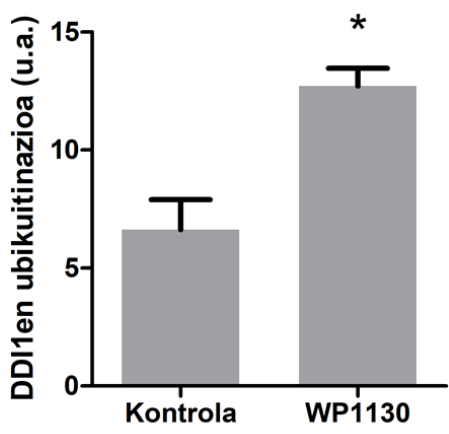

\subsection{WP1130 farmakoaren erabilera Angelman sindromearen eredu diren eulietan}

Orain arte, Angelman sindromea sendatzeko egin diren ikerketa gehienak burmuinean UBE3A funtzionala berrezartzen saiatu dira (9). Aurrez aipatu bezala, guk uste dugu DDI1 proteinaren gutxieneko ubikuitinazio-maila mantentzeak gaixoen sintomatologia eta, ondorioz, bizikalitatea hobe ditzakeela. Ildo horretatik, WP1130 farmakoa DDI1 proteinaren ubikuitinaziomaila igotzeko erabilgarria dela frogatu dugu. Beraz, hurrengo pausoa, farmako horrek gaixotasunaren sintomatologia hobe dezakeen aztertzea izan da.

Atal honetan, UBE3A generik ez duen Drosophila melanogaster eulia erabili dugu, fruta-eulia ere deitua. Euli horiek ez dute UBE3A proteinarik, Angelman sindromea duten pazienteen antzera. Sintomatologiari dagokionez, gizakiek orekaren eta mugimenduen nahasmendua erakusten duten bezala, UBE3A gabeko euliek ere ohikoa duten hodian gora egiteko ahalmena gutxituta daukate, hots, euli osasuntsuek baino denbora gehiago behar dute hodiaren goiko aldera hegan egiteko. Ikerketa honetan, UBE3Arik gabeko fruta-euliei WP1130 farmakoa gehituz gero, hodian gora egiteko duten ahalmena berreskuratzen ote duten aztertu nahi izan dugu.

Horretarako, UBE3A proteinarik ez duten euliak (mutaziodunak) eta euli osasuntsuak erabili ditugu. Bai euli mutaziodunekin, bai osasuntsuekin, talde bi egin dira. Talde bati 0,7 mM WP1130 farmako gehitu diogu dietan 24 orduz; bigarren taldeari, berriz, ez (kontrol-taldea). Hodian gora egiteko ahalmena testatzeko, euliak $4 \mathrm{~cm}$-ko altuerara lerro bat marraztuta duten hodi garbietan sartu ditugu. Jarraian, hodi bakoitzari kolpe bat eman diogu euliak beheko aldera eror daitezen. Momentu horretatik zenbatzen hasita, lehenengo euliak lerroa gurutzatzeko behar duen denbora neurtu dugu (7A irudia). Espero bezala, farmakoa jaso duten eta ez duten euli osasuntsuen artean ez dugu hodian gora egiteko ahalmenean aldaketarik nabaritu (6B irudia). Aldiz, UBE3A proteinarik ez duten eulietan, kontrol-taldeak 15-20 segundo behar izan ditu hodian gora iristeko. Aldiz, WP1130 farmakoarekin tratatutako euli mutanteek 3-4 segundo behar izan dituzte, ia euli osasuntsuen antzeko denbora (7B irudia). Horrek erakusten du, WP1130 farmakoari esker, Angelman sindromearen eredu diren euliek hodian gora igotzeko ahalmena berreskuratzen dutela. Horrek pentsarazten digu, USP9X itu terapeutiko egokia izan daitekeela etorkizunean Angelman sindromea pairatzen duten gaixoen sintomak tratatzeko. 
7. irudia. WP1130 farmakoak Angelman sindromearen eredu diren eulien sintomatologian duen eragina. A) Hodian gora hegan egiteko ahalmena neurtzeko esperimentua. Hodia beheko aldetik $4 \mathrm{~cm}$-ra markatzen da, bertan euliak sartu eta lehenengo euliak marra hori gurutzatzeko behar duen denbora neurtzen da. B) WP1130 farmakoaren bidez UBE3A proteinarik ez duten euli mutaziodunek hodian gora egiteko ahalmena berreskuratzen dute, ia euli osasuntsuen maila arte [ANOVA, ${ }^{* * *}, \mathrm{P}<0,0001, \mathrm{n}=3$ ].

A

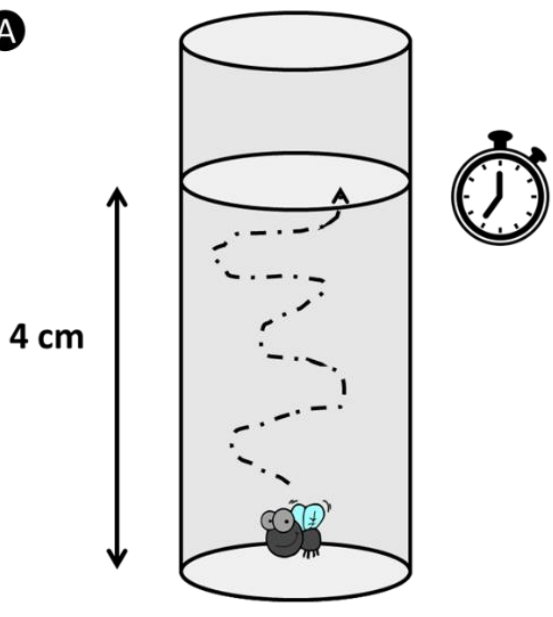

B

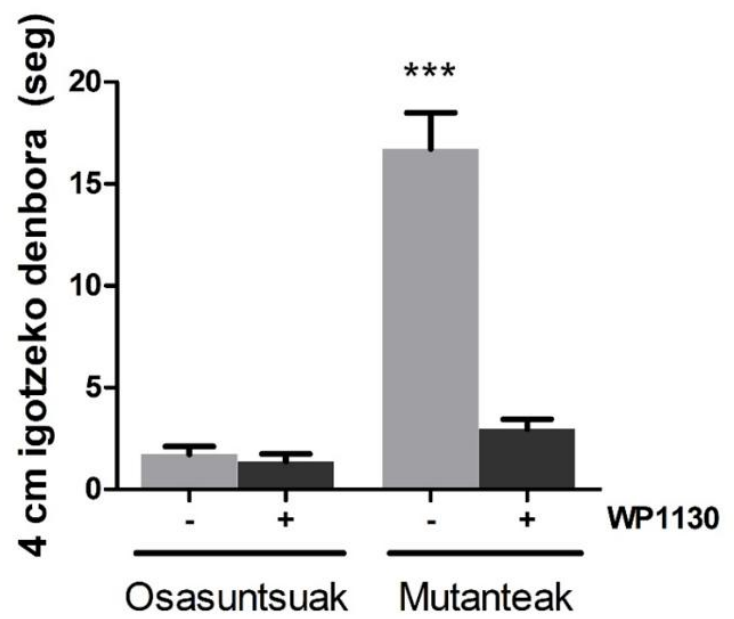

\section{Ondorioak}

Ikerketa honetan UBE3A proteinaren substratua den DDI1 proteinatik ubikuitina kentzeaz arduratzen den DUB proteina identifikatu dugu: USP9X. Proteina horren inaktibazioa pazienteen tratamendurako bidea izan daitekeen frogatzeko asmoz, batetik, isildu egin dugu giza zeluletan, eta bestetik, farmako baten bidez inaktibatu dugu. Kasu bietan DDI1 proteinaren ubikuitinazioa igo denez, gaixotasunaren sintomak benetan arintzeko onuragarria izan daitekeen testatu nahi izan dugu. Angelman sindromearen eredu diren euliek farmakoarekin gutxituta duten hodian gora egiteko ahalmena berreskuratu dutela ikusi dugu, eta, beraz, USP9X proteina etorkizunean testatzeko itu terapeutiko egokia izan daitekeela ondorioztatu dugu.

Egia da giza genomak ehun deubikuitinasa inguru kodetzen dituela, eta, beraz, DUB baten inhibizioak substratu baten baino gehiagoren ubikuitinazio-maila alda dezakeela, albo-kalteak eraginez. Hori ekiditeko, badira gaixotasunaren tratamendu bat lortzeko beste bide batzuk ere. Aurrez aipatu bezala, horietako batzuek UBE3A proteina garunean berrezartzea dute helburu (9). Alabaina, urteetan zehar hainbat gaixotasun neurologikoren tratamenduetarako DUBak ituratu izan dira (10). Horrez gain, gaur egun oraindik ez dira USP9X proteinaren substratu asko ezagutzen, eta berau inaktibatzeak ez du albo-kalte larririk eragin gure ikerketan. Hortaz, hori guztia kontuan izanda, estrategia hau ASaren sintomatologia hobetzeko bide egokia izan daitekeela deritzogu.

\section{Etorkizunerako planteatzen den norabidea}

Lan honetan eakutsi dugunez, UBE3A proteinaren substratua den DDI1 proteinatik ubikuitina kentzeaz arduratzen den DUBa inaktibatzeak eulietan ASaren antzeko sintomatologia arintzen du. Alabaina, UBE3Ak zelulako beste hainbat proteina ubikuitinatzen ditu. Modu bertsuan, DDI1 proteinatik ubikuitina kentzeaz arduratzen diren DUB gehiago ere egon daitezke. Hortaz, beharrezkoa da proteina horiek guztiak ikertu eta zelulan duten funtzioa argitzea benetan gaixotasunaren mekanismo molekularra ulertu ahal izateko. 
Bestalde, UBE3AK DDI1 proteina ubikuitinatzen duela dakigun arren, oraindik ez dago argi ubikuitinazio horren mezua zein den. Egiten ari garen ikerketek erakutsi digute UBE3A bidezko DDI1 proteinaren ubikuitinazioak DDI1a inaktibatzeko balio lezakeela. DDI1ak proteinen birziklapenean duen garrantzia aintzakotzat hartuta, pentsatzekoa da markaketa horren faltak proteinen gehiegizko birziklapena eragin dezakeela, eta, ondorioz, neuronen funtzioetan nahasmenduak eragin. Edonola ere, hori momentuz hipotesi bat besterik ez da eta, beraz, frogatu beharra dago.

Azkenik, frogatu dugu WP1130 farmakoak eulietan ASaren pareko sintomen gain eragin positiboa duela. Hortaz, hurrengo erronka da frogatzea ikerketa honetan ikusitako efektu onuragarri hori Angelman sindromearen hurbilagoko eredu diren saguetan ere agertzen dela, kasu honetan ager daitezkeen albo-kalteak ere aztertuz. Izan ere, horrek guztiak erakutsiko digu ea etorkizunean USP9Xa inhibitzen duen farmakoa ASaren tratamendurako erabilgarria izan daitekeen edo ez.

\section{Eskerrak eta oharrak}

Eskerrak nire taldekide guztiei lan honetan emandako laguntza guztiagatik. Mila esker Josean Rodriguezi eta Ane Olazabali DUBen isilarazpenerako materiala uzteagatik. Azkenik, eskertu baita ere Euskal Herriko Unibertsitateari eta Eusko Jaurlaritzari, doktoretza-programa batean parte hartzeko eta lan hau burutzeko aukera emateagatik.

\section{Erreferentziak}

1. Kishino T, Lalande M, Wagstaff J. UBE3A/E6-AP mutations cause Angelman syndrome. Nat Genet. 1997 Urt;15(1):70-73.

2. Buiting $\mathrm{K}$, Williams $\mathrm{C}$, Horsthemke $\mathrm{B}$. Angelman syndrome - insights into a rare neurogenetic disorder. Nat Rev Neurol. 2016 Urr;12(10):584-593.

3. Swatek KN, Komander D. Ubiquitin modifications. Cell Res. 2016 Api;26(4):399-422.

4. Glickman $\mathrm{MH}$, Ciechanover A. The Ubiquitin-Proteasome Proteolytic Pathway: Destruction for the Sake of Construction. Physiol Rev. 2002 Api 1;82(2):373-428.

5. Wang P-Y, Chang K-T, Lin Y-M, Kuo T-Y, Wang G-S. Ubiquitination of MBNL1 Is Required for Its Cytoplasmic Localization and Function in Promoting Neurite Outgrowth. Cell Rep. 2018 Ots;22(9):2294-2306.

6. Dynek JN, Goncharov T, Dueber EC, Fedorova AV, Izrael-Tomasevic A, Phu L, Helgason E, Fairbrother WJ, Deshayes K, Kirkpatrick DS, Vucic D.. c-IAP1 and UbcH5 promote K11-linked polyubiquitination of RIP1 in TNF signalling. EMBO J. 2010 Abe 15;29(24):4198-4209.

7. Amerik $A Y$, Hochstrasser $M$. Mechanism and function of deubiquitinating enzymes. Biochim Biophys Acta BBA - Mol Cell Res. 2004 Aza 29;1695(1):189-207.

8. Ramirez J, Lectez B, Osinalde N, Sivá M, Elu N, Aloria K, et al. Quantitative proteomics reveals neuronal ubiquitination of Rngo/Ddi1 and several proteasomal subunits by Ube3a, accounting for the complexity of Angelman syndrome. Hum Mol Genet. 2018 Eka 1;27(11):1955-1971.

9. Meng L, Ward AJ, Chun S, Bennett CF, Beaudet AL, Rigo F. Towards a therapy for Angelman syndrome by targeting a long non-coding RNA. Nature. 2015 Ots 19;518(7539):409-412.

10. Osinalde N, Duarri A, Ramirez J, Barrio R, Perez de Nanclares G, Mayor U. Impaired proteostasis in rare neurological diseases [Internet]. Semin Cell Dev Biol. 2018 [Kontsulta: 2019-06-12] 3. pii: S1084-9521(18)30161-7. Eskuragarri: http://www.sciencedirect.com/science/article/pii/S1084952118301617 